\title{
Fissidens (Fissidentaceae, Bryophyta) species newly recorded in Korea
}

\author{
Woochan KWON ${ }^{1,2 *}$ \\ ${ }^{1}$ Division of Environmental Science and Ecological Engineering, Korea University, Seoul 02841, Korea \\ ${ }^{2}$ InfoBoss Inc., and InfoBoss Research Center, Seoul 06088, Korea \\ (Received 14 February 2021; Revised 22 March 2021; Accepted 23 March 2021)
}

\begin{abstract}
Here, 15 taxa of genus Fissidens Hedw. are reported as new to the moss flora of Korea: F. bryoides var. esquirolii, F. closteri subsp. kiusiuensis, F. crispus, F. curvatus, F. enervis, F. flabellulus, F. ganguleei, $F$. gracilifolius, $F$. gymnandrus, $F$. incurvus, F. longisetus, F. pusillus, F. takayukii, F. viridulus, and F. wichurae. The list of Fissidens in Korea, consisting of 26 taxa previously, is updated to 38 taxa by adding 15 taxa and excluding three taxa. Descriptions, taxonomic notes with diagnoses, in situ and microscopic photographs of the unrecorded species, and taxonomic keys of four sections belonging to the subgen. Fissidens are provided.
\end{abstract}

Keywords: Fissidens, mosses, bryophyte, unrecorded species

Genus Fissidens Hedw. is the largest genus among all moss genera in the world. For a while, there were two largest moss genera, Fissidens and Bryum Hedw., which consisted of approximately 440 species, respectively (Crosby et al., 2000). Meanwhile, even after the genus Bryum was split into several genera (Spence, 2005, 2007), the genus Fissidens is still recognized as a single genus (Syazwana et al., 2018).

Genus Fissidens indicates highly complicated diversity with numerous species. Certain species of Fissidens, such as $F$. bryoides Hedw., F. grandifrons Bridel, and F. curvatus Hornsch. are broadly distributed or cosmopolitan (BruggemanNannenga et al., 1994; Bruggeman-Nannenga and Pursell, 1995; Pursell and Allen, 2017). However, most species of Fissidens have relatively limited distributions. For instance, $F$. geppii M. Fleisch., F. tosaensis Broth., and F. ganguleei Nork. are only found in Asia (Li et al., 2001), F. celticus Paton is distributed in Europe (Vanderpoorten and Sotiaux, 2002), and F. appalachensis R. H. Zander is endemic to eastern North America (Pursell and Allen, 1996). On the other hand, there are some species treated differently in several respective countries, e.g. F. bryoides complex: F. viridulus (Sw.) Wahlenb., F. gymnandrus Buse, F. incurvus Starke ex Röhl., F. pusillus (Wilson) Milde (Huttunen et al., 2018). In several European countries, these taxa are recognized as distinct species or varieties of F. bryoides (Huttunen et al., 2018). By contrast, in North America, most of these taxa are regarded as synonyms of $F$. bryoides (Pursell, 2007). After the 2010s, Japanese authors recorded $F$. viridulus, $F$. incurvus, and $F$. pusillus in Japan (Suzuki and Iwatsuki, 2012a), thus the distributions of the species were expanded from Europe to Asia. Considering that these taxa were described as 'expressions' in North America (Pursell and Allen, 2017), the members of $F$. bryoides complex seem to be widely distributed in the Northern Hemisphere.

In Asia, the five varieties of F. bryoides, var. bryoides, var. lateralis, var. ramosissimus, var. esquirolii, and var. schmidii, were classified into F. bryoides complex (Noguchi, 1987; Li et al., 2001). While the variety schmidii was treated as a synonym of Fissidens crispus Mont. (Shevock et al., 2013), the remaining three varieties except var. bryoides are still recognized only in Asia. The descriptions of $F$. bryoides var. esquirolii and $F$. bryoides var. ramosissimus were similar to those of European species, F. exiguus Sull. and F. bambergeri Schimp., respectively. Thus, comparative analysis between the Asian varieties and other species of $F$. bryoides complex should be considered.

To investigate the taxonomically controversial taxa, molecular phylogenetic approaches are necessary for understanding the relationship among similar taxonomic groups. Also, the investigation of F. bryoides complex had

\footnotetext{
*Author for correspondence: whitebean@korea.ac.kr
} 
demanded systematic studies, but previous research was not sufficient to examine the species complex (Huttunen et al., 2018). Meanwhile, Kwon et al. (2019a) reported the first chloroplast genome sequence of Fissidens, and it is expected that high-resolution sequences such as the organelle genome will be the key for unraveling the species complex. Before the molecular phylogenetic studies based on organelle genome sequences of Fissidens species, 15 taxa of collected Fissidens including five taxa of $F$. bryoides complex were newly recorded in Korea from the voucher specimens of Fissidens collected during floristic surveys of Korean moss flora.

Since the first report of Fissidens from the Korean Peninsula (Cardot, 1904), several researchers contributed to the gradual accumulation of the Fissidens flora of Korea (Kim et al., 2020a) during the comprehensive bryofloristic surveys on the Korean Peninsula (Lee and Choi, 2012). After Park and Choi (2007) published a new list of Korean bryophytes including 16 taxa of Fissidens, Korean authors reported various unrecorded species of Fissidens in South Korea (Yoon and Sun, 2010; Yoon et al., 2015a, b; Kwon et al., 2019b; Kim et al., 2020b). Recently, Kim et al. (2020a) organized the list of mosses of the Korean Peninsula and listed 26 taxa of Fissidens as recognized in Korea, including three newly recorded Fissidens species. However, three taxa from the list had to be excluded for the following reasons: (1) F. pellucidus var. asterodontius (Müll. Hal.) Pursell is not recognized in Asia, and the taxon is endemic to Brazil (Pursell, 1994; Bordin et al., 2011), and (2) F. pseudolateralis Cardot and $F$. borealis $C$. Gao are recognized as synonyms of F. geppii and F. bryoides, respectively (Noguchi, 1987; Li et al., 2001). In this study, I also updated the list of Fissidens in Korea consisting of a total of 38 taxa of Fissidens, covering three subgenera and five sections (Appendix 1).

\section{Materials and Methods}

All specimens of Fissidens were collected in Korea during the field surveys from 2018 to 2020 . The voucher specimens of unrecorded species were deposited in the InfoBoss Cyber Herbarium (IN). The infrageneric classification and key to sections of the genus followed the recent molecular phylogenetic study (Suzuki et al., 2018). The keys to species were revised from those of previous studies in several countries (Li et al., 2001, Smith, 2004; Suzuki, 2015; Erzberger, 2016).

\section{Taxonomic Treatment}

\section{I. subgen. Fissidens sect. Fissidens}

1. Fissidens bryoides var. esquirolii (Thér.) Z. Iwats. \& T.
Suzuki, J. Hattori Bot. Lab. 51: 361, 1982 (Figs. 1A, 2A).

Fissidens esquirolii Thér., Bull. Acad. Int. Géogr. Bot. 18: 251, 1908.

Fissidens yamamotoi Sakurai, Bot. Mag. (Tokyo) 56: 218, 1952.

Korean name: Jom-kko-ma-bong-hwang-i-kki (좀꼬마봉 황이끼).

Plants yellowish green to brownish green, $0.8-1.2 \mathrm{~mm}$ long and $0.5-0.8 \mathrm{~mm}$ wide with leaves. Stems unbranched; axillary hyaline nodules not differentiated. Leaves in 3-4 pairs, upper leaves oblong-lanceolate to ovate-lanceolate, $0.4-0.8 \times 0.15-$ $0.20 \mathrm{~mm}$, acute at apex; base of dorsal laminae wedge-shaped; costae ending few cells below apex; margins finely serrulate to crenulate throughout by projecting cells; vaginant laminae ca. 3/5-2/3 the leaf length, almost equal; limbidia absent or rarely developed, unistratose, 1-2 rows of elongate cells on the vaginant laminae of perichaetial leaves; laminal cells unistratose, smooth; cells in the middle of apical and dorsal laminae quadrate to hexagonal, (8-)10-15(-18) $\mu \mathrm{m}$ long; cells in the vaginant laminae similar to those of apical and dorsal laminae, elongated to rectangular near the base, up to $25 \mu \mathrm{m}$ long. Sporophytes not seen.

Specimens examined: KOREA. Gangwon-do: Samcheoksi, Gapbongsan Mountain, elev. 70 m, 21 Dec 2019, W. Kwon KBDS02616 (IN); Yeongwol-gun, Balbonsan Mountain, elev. 300 m, 26 Apr 2020, W. Kwon KBDS03180 (IN).

Habitats: on moist calcareous rocks near the stream.

Distribution: China, Japan, Taiwan, Thailand; new to Korea.

The East Asian variety, F. bryoides var. esquirolii, is characterized by its markedly reduced limbidia. Its limbidia are only found on the vaginant laminae of perichaetial leaves (Li et al., 2001), while other members of sect. Fissidens commonly have at least rather differentiated limbidia on their cauline leaves. It was originally described in China as the basionym F. esquirolii Thériot (1908) and described in Japan as a synonym $F$. yamamotoi Sakurai (1942). After the taxon was treated as a variety of $F$. bryoides (Iwatsuki and Suzuki, 1982), it was also recognized in Taiwan and Thailand additionally (Tan et al., 2006). Two European taxa of sect. Fissidens, F. arnoldii R. Ruthe and F. exiguus Sull. are also characterized by their limbidia limited to the vaginant laminae of perichaetial leaves (Erzberger, 2016). However, leaf margins of those two species were described as slightly crenulate and entire respectively, contrary to F. bryoides var. esquirolii having serrulate margins.

The Korean name was given as 'Jom-kko-ma-bong-hwangi-kki', based on its minute plants size. 


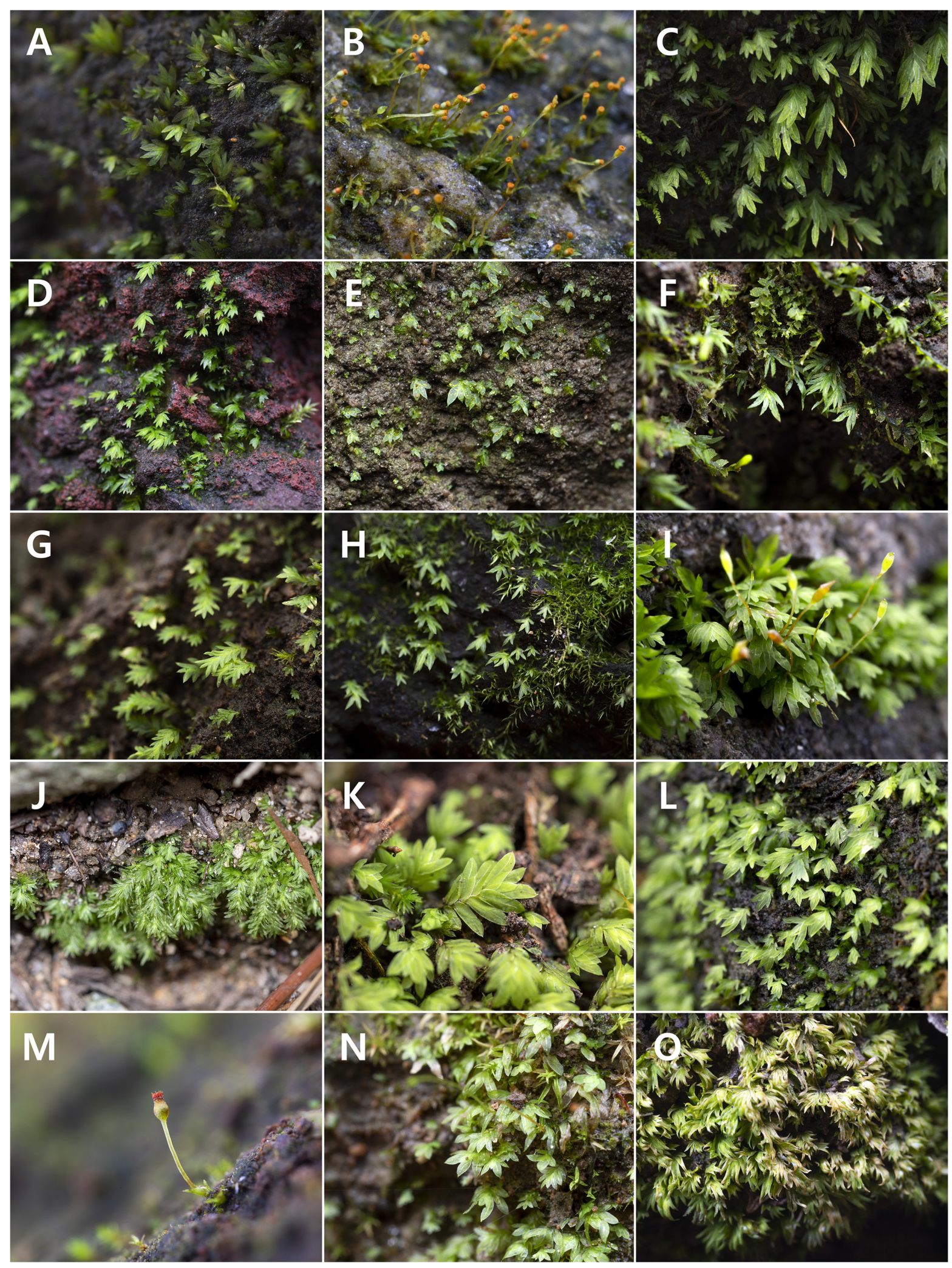

Fig. 1. Photographs of the 15 unrecorded Fissidens in Korea. A. F. bryoides var. esquirolii (Thér.) Z. Iwats. \& T. Suzuki. B. F. closteri subsp. kiusiuensis (Sakurai) Z. Iwats. C. F. crispus Mont. D. F. curvatus Hornsch. E. F. enervis Sim. F. F. flabellulus Thwait. \& Mitt. G. F. ganguleei Nork. H. F. gracilifolius Brugg.-Nann. \& Nyholm. I. F. gymnandrus Buse. J. F. incurvus Starke ex Röhl. K. F. longisetus Griff. L. F. pusillus (Wilson) Milde. M. F. takayukii Tad. Suzuki. N. F. viridulus (Sw.) Wahlenb. O. F. wichurae Broth. \& Fleisch. 


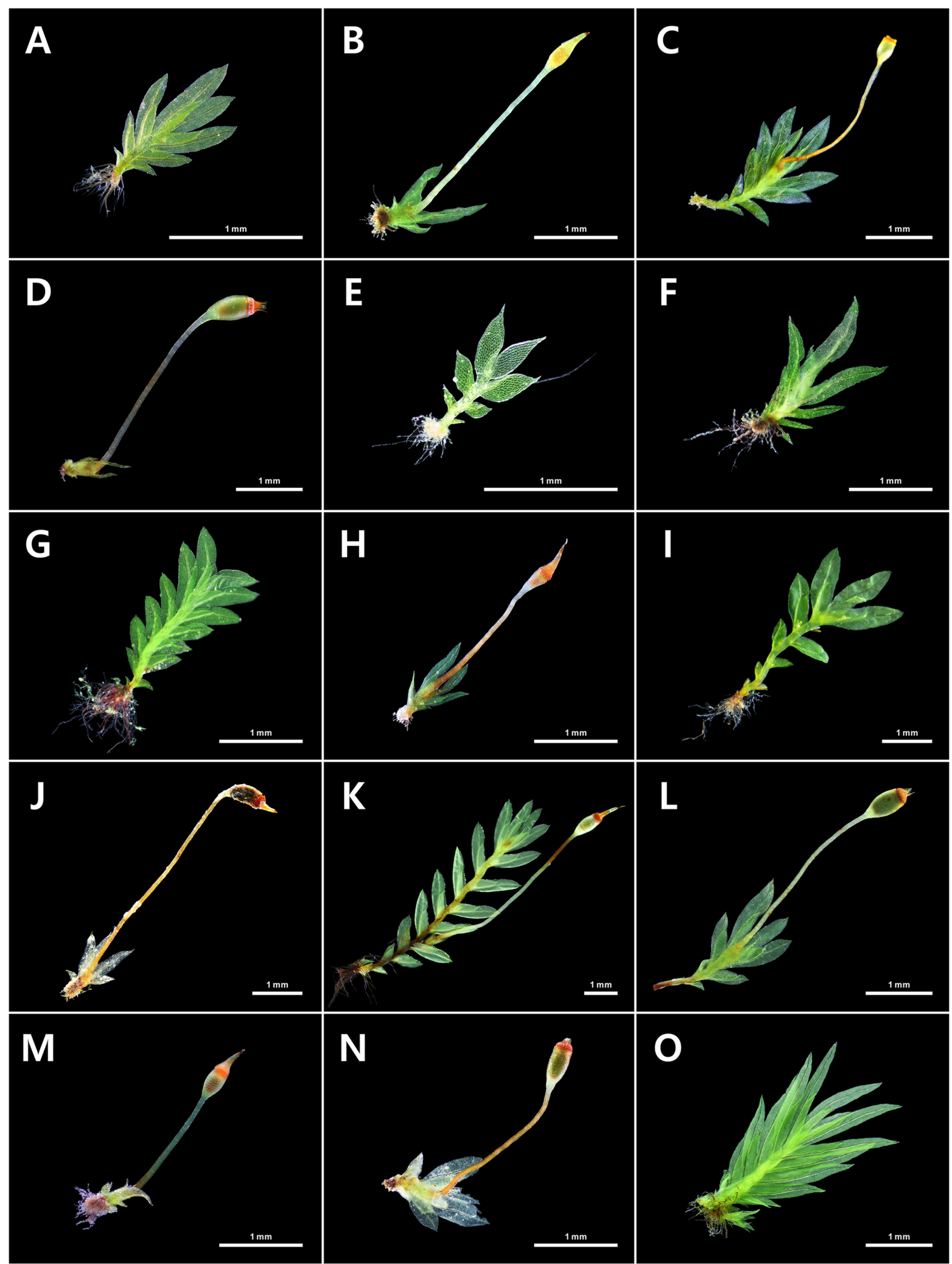

Fig. 2. Microscopic photographs of the 15 unrecorded Fissidens in Korea. A. F. bryoides var. esquirolii (Thér.) Z. Iwats. \& T. Suzuki. B. F. closteri subsp. kiusiuensis (Sakurai) Z. Iwats. C. F. crispus Mont. D. F. curvatus Hornsch. E. F. enervis Sim. F. F. flabellulus Thwait. \& Mitt. G. F. ganguleei Nork. H. F. gracilifolius Brugg.-Nann. \& Nyholm. I. F. gymnandrus Buse. J. F. incurvus Starke ex Röhl. K. F. longisetus Griff. L. F. pusillus (Wilson) Milde. M. F. takayukii Tad. Suzuki. N. F. viridulus (Sw.) Wahlenb. O. F. wichurae Broth. \& Fleisch. 
2. Fissidens crispus Mont., Ann. Sci. Nat., Bot., sér. 2., 9: 57, 1838 (Figs. 1C, 2C).

Fissidens schmidii Müll. Hal., Bot. Zeit. (Berlin) 11: 18, 1853; Fissidens bryoides var. schmidii (Müll. Hal.) R.S. Chopra \& S.S. Kumar, Ann. Cryptog. Phytopathol. (New Delhi) 5: 43, 1981.

Fissidens limbatus Sull., Expl. Railroad Mississippi Pacific, Descr. Moss. Liverw. 4: 185, 1856.

Korean name: San-kko-ma-bong-hwang-i-kki (산꼬마봉 황이끼).

Plants green to vivid green, $2.0-3.5 \mathrm{~mm}$ long and 0.8-2.0 $\mathrm{mm}$ wide with leaves. Stems unbranched; axillary hyaline nodules \pm weakly differentiated. Leaves in 4-8 pairs, upper leaves elliptical-lanceolate to linear lanceolate, $0.8-1.8 \times 0.2-$ $0.4 \mathrm{~mm}$, acute at apex; perichaetial leaves differentiated, much longer than cauline leaves; base of dorsal laminae wedgeshaped; costae nearly percurrent to shortly excurrent; margins entire; vaginant laminae ca. 1/2 the leaf length, equal; limbidia usually uni- to bistratose, nearly extending to the apex; laminal cells unistratose, smooth; cells in the middle of apical and dorsal laminae quadrate to hexagonal, 4-10 $\times 4-7 \mu \mathrm{m}$, strongly bulging (twice as high as wide in cross-section); cells in the vaginant laminae less bulging than those of apical and dorsal laminae, elongated toward base; basal juxtacostal cells of vaginant laminae rectangular, gradually enlarged, up to $30 \mu \mathrm{m}$ long. Rhizautoicous or synoicous. Archegonia terminal on stems, 230-290 $\mu \mathrm{m}$ long. Antheridia terminal on minute budlike or normal-sized male shoots, ca. $180 \mu \mathrm{m}$ long. Setae 2.0$2.5 \mathrm{~mm}$ long. Capsules symmetrical, erect, urns $0.33-0.45 \times$ $0.22-0.25 \mathrm{~mm}$; peristome teeth $0.14-0.20 \mathrm{~mm}$ long, $27-33 \mu \mathrm{m}$ wide at base. Spores $12-15 \mu \mathrm{m}$ in diameter. opercula and calyptrae not seen.

Specimens examined: KOREA. Gangwon-do: Samcheoksi, Galmaegisan Mountain, elev. 240 m, 20 Aug 2019, W. Kwon KBDS02346 (IN); Jeongseon-gun, Unbongsan Mountain, elev. 270 m, 16 Jul 2020, W. Kwon KBDS03370 (IN).

Habitats: on dry limestone rocks in the small valley.

Distribution: widely distributed in tropics to temperate regions; new to Korea.

Fissidens crispus is characterized by its small protuberant laminal cells mostly twice as deep as wide in cross-section, of which trait is shared with $F$. ovatifolius $\mathrm{R}$. Ruthe and $F$. sublimbatus Grout (Corley, 1980; Ros et al., 2001). This species is also well known as its synonym, F. limbatus Sull. in North America (Pursell, 2007) and F. schmidii or F. bryoides var. schmidii in Asia (Tan et al., 2006). F. schmidii was treated as a synonym of F. crispus (Bruggeman-Nannenga, 2013;
Shevock et al., 2013), while the synonymy of $F$. minutulus Sull. and F. crispus was not clearly determined (Hill et al., 2006). F. minutulus was recognized as a synonym of $F$. crispus in Europe while the two taxa were regarded as distinct species in North America (Erzberger, 2016).

The Korean name was given as 'San-kko-ma-bong-hwangi-kki', based on its habitats.

3. Fissidens curvatus Hornsch., Linnaea. 15: 148, 1841 (Figs. 1D, 2D).

Fissidens strictulus Müll. Hal., Nuov. Giorn. Bot. Ital., n.s. 5: $159,1898$.

Korean name: Beo-deul-bong-hwang-i-kki (버들봉황이끼).

Plants pale green to yellowish green, 1.5-3.0 mm long and $0.5-0.7 \mathrm{~mm}$ wide with leaves. Stems unbranched; axillary hyaline nodules differentiated; fertile and sterile stems dimorphic; fertile stems short, variable, with much longer leaves than sterile stems, or with somewhat reduced, scale-like leaves. Leaves in 5-9 pairs, upper leaves linear-lanceolate, 0.7$0.8 \times 0.15-0.17 \mathrm{~mm}$, acuminate at apex; perichaetial leaves differentiated, much longer than cauline leaves, or shorter with somewhat reduced apical and dorsal laminae; base of dorsal laminae wedge-shaped; costae percurrent to shortly excurrent; margins entire; vaginant laminae ca. 3/5-2/3 the leaf length, almost equal; limbidia uni- to bistratose, thin-walled, confluent with the costa; laminal cells unistratose, smooth; cells in the middle of apical and dorsal laminae narrowly hexagonal, 7$17 \mu \mathrm{m}$ long and 5-8 $\mu \mathrm{m}$ wide; cells in the vaginant laminae similar to those of apical and dorsal laminae but somewhat regularly arranged, elongated to rectangular near the base, up to $25 \mu \mathrm{m}$ long. Rhizautoicous. Archegonia terminal, 180-210 $\mu \mathrm{m}$ long. Antheridia terminal on minute bud-like male shoots, 110-170 $\mu \mathrm{m}$ long. Setae 3.0-3.5 mm long. Capsules symmetrical, erect to slightly inclined, urns $0.50-0.65 \times 0.35-$ $0.40 \mathrm{~mm}$; opercula conic-rostellate, $0.27-0.33 \mathrm{~mm}$ long; calyptrae cucullate, ca. $0.4 \mathrm{~mm}$ long; peristome teeth $0.27-$ $0.30 \mathrm{~mm}$ long, $36-40 \mu \mathrm{m}$ wide at base. Spores $16-21 \mu \mathrm{m}$ in diameter.

Specimens examined: KOREA. Jeju-do: Seogwipo-si, Changgocheon Stream, elev. 190 m, 19 Jan 2020, W. Kwon KBDS02652 (IN); Seogwipo-si, Jungmuncheon Stream, elev. 140 m, 19 Jan 2020, W. Kwon KBDS02714 (IN); Seogwiposi, Dosuncheon Stream, elev. 100 m, 20 Jan 2020, W. Kwon KBDS02738 (IN).

Habitats: on clayey soil and moist rocks on the banks of the ephemeral streams.

Distribution: Africa, Asia, Australasia, Europe, North and 
South America; new to Korea.

Fissidens curvatus is a cosmopolitan species, widely distributed in all continent except Antarctica (BruggemanNannenga and Pursell, 1995). This species is characterized by (1) stout limbidia that are confluent with costa, (2) large, slightly elongated laminal cells, and (3) dimorphic sterile and fertile stems (Pursell 2007; Bruggeman-Nannenga, 2013). Its longly tapering leaves with well-developed limbidia are quite distinct from other limbate species (Atherton et al., 2010).

The Korean name was given as 'Beo-deul-bong-hwang-ikki', based on its leaf shape.

4. Fissidens gracilifolius Brugg.-Nann. \& Nyholm, Ill. Fl. Nord. Mosses 1: 10, 1986 (Figs. 1H, 2H).

Korean name: Ga-neun-dol-kko-ma-bong-hwang-i-kki (가 는돌고마봉황이끼).

Plants green to pale green, $1.8-2.5 \mathrm{~mm}$ and $1.0-1.5 \mathrm{~mm}$ wide with leaves. Stems unbranched; axillary hyaline nodules not differentiated; fertile stems dimorphic, female shoots are smaller with fewer leaves or somewhat larger than sterile shoots. Leaves in 2-6 pairs, upper leaves oblong-lanceolate to linear lanceolate, $0.9-1.5 \times 0.10-0.25 \mathrm{~mm}$, acuminate at apex; perichaetial leaves differentiated, much longer than cauline leaves, ca. 7 times as long as wide; base of dorsal laminae wedge-shaped; costae percurrent to shortly excurrent; margins entire; vaginant laminae ca. 1/2 the leaf length, equal; limbidia usually unistratose, ending below apex; laminal cells unistratose, smooth; cells in the middle of apical and dorsal laminae quadrate to hexagonal, $9-15 \times 6-9 \mu \mathrm{m}$; cells in the vaginant laminae similar to those of apical and dorsal laminae, \pm elongated toward base; basal juxtacostal cells of vaginant laminae rectangular, somewhat enlarged, up to $25 \mu \mathrm{m}$ long. Rhizautoicous. Archegonia terminal, 200-250 $\mu \mathrm{m}$ long. Antheridia terminal, $120-180 \mu \mathrm{m}$ long. Setae $1.3-3.0 \mathrm{~mm}$ long. Capsules symmetrical, erect, urns $0.30-0.62 \times 0.20-0.33 \mathrm{~mm}$; opercula rostellate, $0.20-0.33 \mathrm{~mm}$ long; calyptrae cucullate, 0.35-0.50 mm long; peristome teeth $0.14-0.20 \mathrm{~mm}$ long, 25$34 \mu \mathrm{m}$ wide at base. Spores $10-14 \mu \mathrm{m}$ in diameter.

Specimens examined: KOREA. Gyeongsangbuk-do: Gimcheon-si, Sudosan Mountain, elev. 950 m, 5 Sep 2020, W. Kwon KBDS03742 (IN).

Habitats: on rocks near the stream.

Distribution: Europe, China, Japan; new to Korea.

Fissidens gracilifolius is a small saxicolous species, characterized by (1) narrowly lanceolate leaves with unistratose limbidia ending below the acuminate apex, and (2) elongated perichaetial leaves approximately 7 times as long as wide
(Erzberger, 2016). These two characteristics separate $F$. gracilifolius from the confusable species, F. pusillus, which has perichaetial leaves 4-6 times as long as wide (Smith, 2004; Erzberger, 2016). Though features of costa and leaf apex of both species are variable, the perichaetial leaves of $F$. gracilifolius have acuminate apex with excurrent costa, while those of $F$. pusillus have acute to obtuse apex and costa usually ending below the apex (Smith, 2004; Erzberger, 2016). F. gracilifolius is also known as having shorter fertile stems with fewer cauline leaves compared to sterile stems (Suzuki and Iwatsuki, 2012a), and the dimorphism of the stems may separate $F$. gracilifolius from F. pusillus. Meanwhile, Korean materials had another type of fertile stems, undifferentiated from sterile stems but having somewhat larger leaves, coexisting with typical short fertile stems.

The Korean name was given as 'Ga-neun-dol-kko-ma-bonghwang-i-kki', based on its narrow leaves and saxicolous habitats.

5. Fissidens gymnandrus Buse, Hedwigia 8: 55, 1869 (Figs. 1I, 2I).

Korean name: Min-kko-ma-bong-hwang-i-kki (민꼬마봉 황이끼)

Plants pale green to vivid green, 3.0-5.0 $\mathrm{mm}$ long and 1.5$2.5 \mathrm{~mm}$ wide with leaves. Stems unbranched; axillary hyaline nodules not differentiated. Leaves in 4-7 pairs, upper leaves elliptical-lanceolate to oblong-lanceolate, $1.4-1.7 \times 0.4-0.5$ $\mathrm{mm}$, obtuse to acute or mucronate at apex; perichaetial leaves not differentiated; base of dorsal laminae wedge-shaped; costae nearly percurrent; margins entire; vaginant laminae ca. 1/2-3/ 5 the leaf length, almost equal; limbidia usually unistratose, nearly extending to the apex; laminal cells unistratose, smooth; cells in the middle of apical and dorsal laminae quadrate to hexagonal, $7-17 \times 6-11 \mu \mathrm{m}$; cells in the vaginant laminae similar to those of apical and dorsal laminae; basal juxtacostal cells of vaginant laminae rectangular, gradually enlarged, up to $30 \mu \mathrm{m}$ long. Autoicous, paroicous, or synoicous. Archegonia terminal, 240-290 $\mu \mathrm{m}$ long. Antheridia usually in leaf axils of fertile shoots, without perigonial leaves, 180-200 $\mu \mathrm{m}$ long. Setae 2.0-4.0 mm long. Capsules symmetrical, erect, urns $0.53-0.68 \times 0.23-0.28 \mathrm{~mm}$; opercula conic-rostellate, ca. 0.3 $\mathrm{mm}$ long; calyptrae cucullate, ca. $0.5 \mathrm{~mm}$ long; peristome teeth $0.14-0.20 \mathrm{~mm}$ long, 33-39 $\mu \mathrm{m}$ wide at base. Spores 11-16 $\mu \mathrm{m}$ in diameter.

Specimens examined: KOREA. Gangwon-do: Jeongseongun, Gariwangsan Mountain, elev. 1,120 m, 17 Jul 2020, W. Kwon KBDS03442 (IN). 
Habitats: on decaying woods and soil of mountains (elev. 900-1,300 m).

Distribution: Europe, North America, Japan, Russia; new to Korea.

Fissidens gymnandrus is characterized by its naked axillary antheridia, contrary to $F$. bryoides having antheridia in axillary bud-like perigonia. In the distal part of ovate to elliptical leaves, $F$. gymnandrus has wider leaf apex than that of F. bryoides, forming obtuse apex with short apiculus (Erzberger, 2016). F. gymnandrus is widely distributed in Europe and also reported in Russia, Japan, and North America (Guerra et al., 2012). Although there were a lot of controversies over the taxonomy of F. gymnandrus and F. bryoides (Huttunen et al., 2018), I adopted the basionym of the taxon since phylogenetics of these taxa have not been studied yet.

The Korean name was given as 'Min-kko-ma-bong-hwangi-kki', based on its naked axillary antheridia.

6. Fissidens incurvus Starke ex Röhl. Deutschl. Fl. (ed. 2), Kryptog. Gew. 3: 76, 1813 (Figs. 1J, 2J).

Korean name: Gub-eun-kko-ma-bong-hwang-i-kki (굽은 고마봉황이끼).

Plants green to yellowish green, $2.5-4.0 \mathrm{~mm}$ long and 1.3$2.2 \mathrm{~mm}$ wide with leaves. Stems unbranched; axillary hyaline nodules not differentiated; fertile shoots are smaller than sterile shoots. Leaves in 5-9 pairs, upper leaves ovate-lanceolate to narrowly elliptical, $1.2-1.7 \times 0.3-0.5 \mathrm{~mm}$, acute at apex; perichaetial leaves differentiated, more or less longer and narrower than cauline leaves; base of dorsal laminae wedgeshaped; costae percurrent to excurrent; margins entire; vaginant laminae ca. 3/5-2/3 the leaf length, equal; limbidia welldeveloped, 1-2(-3)-stratose, extending to the apex; laminal cells unistratose, smooth; cells in the middle of apical and dorsal laminae quadrate to hexagonal, $8-15 \times 6-10 \mu \mathrm{m}$; cells in the vaginant laminae similar to those of apical and dorsal laminae; basal juxtacostal cells of vaginant laminae rectangular, gradually enlarged, up to $25 \mu \mathrm{m}$ long. Rhizautoicous. Archegonia terminal, 210-280 $\mu \mathrm{m}$ long. Antheridia terminal on small bud-like male shoots near the base of female shoots, ca. $180 \mu \mathrm{m}$ long. Setae 4.0-6.5(-10.0) mm long. Capsules asymmetrical, inclined, urns $0.58-0.65 \times 0.33-0.38 \mathrm{~mm}$; opercula rostrate, $0.40-0.45 \mathrm{~mm}$ long; calyptrae cucullate, ca. $0.6 \mathrm{~mm}$ long; peristome teeth $0.27-0.33 \mathrm{~mm}$ long, $38-44 \mu \mathrm{m}$ wide at base. Spores $12-15 \mu \mathrm{m}$ in diameter.

Specimens examined: KOREA. Jeollanam-do: Wando-gun, Jeongjusan Mountain, elev. 10 m, 20 Apr 2018, W. Kwon KBDS00520 (IN). Gyeongsangnam-do: Geoje-si, Bukbyeongsan
Mountain, elev. 80 m, 8 Feb 2019, W. Kwon KBDS01324 (IN). Gyeongsangbuk-do: Chilgok-gun, Dongmugol valley, elev. 200 m, 13 Sep 2019, W. Kwon KBDS02573 (IN). Jeju-do: Seogwipo-si, Dosuncheon Stream, elev. 90 m, 20 Jan 2020, W. Kwon KBDS02718 (IN).

Habitats: on soil; rarely on rocks near the streams.

Distribution: Africa, Asia, Australia, Europe, and North America; new to Korea.

Fissidens incurvus is characterized by (1) inclined asymmetric capsules, and (2) short male shoots on the base of female shoots, not axillary (Smith, 2004; Erzberger, 2016). The East Asian species F. tosaensis is closely related to F. incurvus, also recognized by its inclined asymmetric capsules. However, F. tosaensis has axillary male inflorescences, as referred to the original description (Brotherus, 1921). In addition, there is a difference on the female shoots of these species. F. incurvus only has terminal setae while the setae of $F$. tosaensis were described as terminal or lateral (Noguchi, 1987; Li et al., 2001). The Korean materials had small bud-like male shoots on the base of other shoots, and had female shoots somewhat smaller than sterile shoots.

The Korean name was given as 'Gub-eun-kko-ma-bonghwang-i-kki', based on its reduced limbidia.

7. Fissidens longisetus Griff., Calcutta J. Nat. Hist. 2: 503, 1842 (Figs. 1K, 2K).

Korean name: Keun-kko-ma-bong-hwang-i-kki (큰꼬마봉 황이끼).

Plants green to brownish green, 5.0-13.0 mm long and 2.2$3.5 \mathrm{~mm}$ wide with leaves. Stems branched at middle parts of older stems; axillary hyaline nodules not differentiated. Leaves in 7-13 pairs, upper leaves narrowly elliptic to oblonglanceolate, $1.5-2.4 \times 0.2-0.5 \mathrm{~mm}$, mucronate to acuminate at apex; perichaetial leaves \pm differentiated, much narrower than cauline leaves; base of dorsal laminae wedge-shaped; costae excurrent; margins entire; vaginant laminae ca. 3/5-2/3 the leaf length, equal; limbidia usually stoat, confluent with the costa, 2-4-stratose on vaginant laminae, yellowish in older parts; laminal cells unistratose, smooth; cells in the middle of apical and dorsal laminae quadrate to hexagonal, $8-15 \times 6-9 \mu \mathrm{m}$; cells of vaginant laminae similar to those of apical and dorsal laminae; basal juxtacostal cells of vaginant laminae rectangular, conspicuously enlarged, up to $40 \mu \mathrm{m}$ long. Gonioautoicous or synoicous. Archegonia terminal on fertile shoots or short axillary branches, 230-250 $\mu \mathrm{m}$ long. Antheridia terminal on fertile shoots or in axillary bud-like perigonia, ca. $170 \mu \mathrm{m}$ long. Setae 4.0-6.0 mm long. Capsules symmetrical, erect, urns 
$0.65-0.90 \times 0.32-0.40 \mathrm{~mm}$; opercula rostellate, ca. $0.4 \mathrm{~mm}$ long; calyptrae cucullate, ca. $0.8 \mathrm{~mm}$ long; peristome teeth 0.36-0.40 mm long, 44-52 $\mu \mathrm{m}$ wide at base. Spores 14-16 $\mu \mathrm{m}$ in diameter.

Specimens examined: KOREA. Gangwon-do: Samcheoksi, Gapbongsan Mountain, elev. 60 m, 21 Dec 2019, W. Kwon KBDS02606 (IN); Yeongwol-gun, Balbonsan Mountain, elev. 300 m, 26 Apr 2020, W. Kwon KBDS03182 (IN). Chungcheongbuk-do: Chungju-si, Indeungsan Mountain, elev. $290 \mathrm{~m}$, 15 Mar 2020, W. Kwon KBDS03078 (IN).

Habitats: on moist soil and rocks.

Distribution: Europe, North America, Japan; new to Korea. Fissidens longisetus, a member of sect. Fissidens, has relatively large plants that grow up to $1.5 \mathrm{~cm}$ high. This species is characterized by its long setae that are terminal, or lateral growing on short axillary branches. There are two species with lateral setae, $F$. tosaensis and $F$. bryoides var. lateralis, similar to $F$. longisetus. However, F. tosaensis has asymmetric capsules and $F$. bryoides var. lateralis has shorter $(0.8-2.5 \mathrm{~mm})$ setae, while $F$. longisetus has symmetric capsules and longer (5.0$11.0 \mathrm{~mm}$ ) setae (Suzuki and Iwatsuki, 2008).

The Korean name was given as 'Keun-kko-ma-bong-hwangi-kki', based on its large plant size.

8. Fissidens pusillus (Wilson) Milde, Bryol. Siles. 82, 1869 (Figs. 1L, 2L).

Fissidens viridulus var. pusillus Wilson, Bryol. Brit.: 303, 1855.

Korean name: Dol-kko-ma-bong-hwang-i-kki (돌꼬마봉 황이끼).

Plants green to light green, $1.5-2.5 \mathrm{~mm}$ long and 1.0-1.3 $\mathrm{mm}$ wide with leaves. Stems unbranched; axillary hyaline nodules not differentiated. Leaves in 3-7 pairs, upper leaves much larger than lower leaves, oblong-lanceolate to lingulatelanceolate, $0.50-1.50 \mathrm{~mm} \times 0.20-0.35 \mathrm{~mm}$, in upper part suddenly narrowed, acute to obtuse at apex; base of dorsal laminae wedge-shaped; vaginant laminae ca. $1 / 2$ to $3 / 5$ the leaf length, almost equal; perichaetial leaves differentiated, much longer than cauline leaves, 4-6(-7) times as long as wide; margin entire to slightly denticulate at apex; costae ending few cells below apex or percurrent; limbidia usually uni- to bistratose, ending below apex; laminal cells unistratose, smooth; cells in the middle of apical and dorsal laminae quadrate to hexagonal, $(6-) 8-16(-18) \times 4-8(-12) \mu \mathrm{m}$; cells in the vaginant laminae similar to those of apical and dorsal laminae; basal juxtacostal cells of vaginant laminae rectangular, conspicuously enlarged, up to $40 \mu \mathrm{m}$ long. Rhizautoicous.
Archegonia terminal, $240-280 \mu \mathrm{m}$ long. Antheridia terminal on minute bud-like or normal-sized male shoots, 180-220 $\mu \mathrm{m}$ long. Setae 2.5-3.0 mm long. Capsules symmetrical, erect, urns $0.45-0.58 \times 0.24-0.30 \mathrm{~mm}$; opercula conic-rostellate, 0.30 $0.33 \mathrm{~mm}$ long; calyptrae cucullate, ca. $0.6 \mathrm{~mm}$ long; peristome teeth $0.20-0.23 \mathrm{~mm}$ long, $27-32 \mu \mathrm{m}$ wide at base. Spores $12-$ $14 \mu \mathrm{m}$ in diameter.

Specimens examined: KOREA. Gangwon-do: Pyeongchanggun, Cheongoksan Mountain, elev. 990 m, 21 Aug 2019, W. Kwon KBDS02493 (IN); Jeongseon-gun, Gariwangsan Mountain, elev. 600 m, 17 Jul 2020, W. Kwon KBDS03410 (IN).

Habitats: on moist rocks in trails and slopes.

Distribution: Europe, North America, Japan; new to Korea.

This species is characterized by (1) plants usually growing on moist siliceous rocks, up to $5 \mathrm{~mm}$ high, (2) limbidia and costae ending below leaf apex, and (3) leaf margins at apex more or less straight, and (4) perichaetial leaves 4-6 times as long as wide (Erzberger, 2016). This species was described as a hydrophilous species by some authors, contrary to the nonhydrophilous species, F. gracilifolius (Smith, 2004; Erzberger, 2016). In Korea, the species was also found in nonhydrophilous habitats like trails, slopes, and on the top point of the mountain.

The Korean name was given as 'Dol-kko-ma-bong-hwangi-kki', based on its saxicolous habitats.

9. Fissidens viridulus (Sw.) Wahlenb., Fl. Lapp. 334, 1812 (Figs. 1N, 2N).

Dicranum viridulum Sw., Monthly Rev. 34: 538, 1801.

Korean name: Eo-ri-kko-ma-bong-hwang-i-kki (어리꼬마 봉황이끼).

Plants pale green to vivid green, $1.5-4.0 \mathrm{~mm}$ long and 1.0$1.6 \mathrm{~mm}$ wide with leaves. Stems unbranched; axillary hyaline nodules not differentiated. Leaves in 3-5 pairs, upper leaves elliptical-lanceolate to oblong-lanceolate, $0.7-1.3 \times 0.20-0.35$ $\mathrm{mm}$, acute to obtuse-apiculate at apex; perichaetial leaves not differentiated but somewhat larger than cauline leaves; base of dorsal laminae wedge-shaped; costae ending below the apex; margins entire, often finely serrulate at apex with bluntly projected cells; vaginant laminae ca. 3/5 the leaf length, almost equal; limbidia unistratose, ending below apex; laminal cells unistratose, smooth; cells in the middle of apical and dorsal laminae quadrate to hexagonal, $7-15 \times 6-10 \mu \mathrm{m}$; cells in the vaginant laminae similar to those of apical and dorsal laminae; basal juxtacostal cells of vaginant laminae rectangular, gradually enlarged, up to $30 \mu \mathrm{m}$ long. Rhizautoicous. Archegonia terminal, 230-260 $\mu \mathrm{m}$ long. Antheridia terminal 
on minute bud-like or normal-sized male shoots, $150-180 \mu \mathrm{m}$ long. Setae 1.8-3.5(-5.0) mm long. Capsules symmetrical, erect, urns $0.52-0.64 \times 0.26-0.31 \mathrm{~mm}$; opercula conicrostellate, ca. $0.3 \mathrm{~mm}$ long; calyptrae cucullate, ca. $0.4 \mathrm{~mm}$ long; peristome teeth $0.12-0.18 \mathrm{~mm}$ long, $30-37 \mu \mathrm{m}$ wide at base. Spores $12-17 \mu \mathrm{m}$ in diameter.

Specimens examined: KOREA. Gangwon-do: Samcheoksi, Galmaegisan Mountain, elev. 220 m, 20 Aug 2019, W. Kwon KBDS02342 (IN).

Habitats: on soil in the side of trails.

Distribution: Africa, Australia, Europe, North and Central America, and Japan; new to Korea.

Fissidens viridulus is a small terricolous species, characterized by (1) rhizautoicous plants usually with small bud-like male shoots, (2) unistratose limbidia not confluent with costa that ending below leaf apex, (3) leaf margins at apex concave with acuminate or cuspidate apex, and (4) perichaetial leaves not differentiated but somewhat larger than cauline leaves (Smith, 2004; Erzberger, 2016). Like the case of $F$. gymnandrus, this species is also regarded as a expression of $F$. bryoides (Pursell and Allen, 2017). Phylogenetic analysis based on marker sequences was not enough to support the taxon as a distinct species (Hassel et al., 2013), further studies are required.

The Korean name was given as 'Eo-ri-kko-ma-bong-hwangi-kki', based on its relatively reduced limbidia and costae.

\section{Key to the species of subgen. Fissidens sect. Fissidens in Korea}

1. Leaves of sterile stems usually elmbate, limbidia restricted to the vaginant laminae of perichaetial leaves

F. bryoides var. esquirolii

1. Limbidia on all laminae of fully developed cauline leaves

2. Leaves narrowly lanceolate with acute apex; limbidia stoat, confluent at the apex ……………..... F. curvatus

2. Leaves not as above

3. Cells in the middle of dorsal laminae 4-10 $\mu \mathrm{m}$ long, strongly bulging (twice as high as wide in cross-

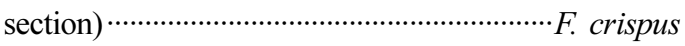

3. Cells in the middle of dorsal laminae 6-15 $\mu \mathrm{m}$ long, not or scarcely bulging

4. Capsules inclined, asymmetrical

5. Setae terminal; male inflorescences mostly at the base of fertile shoots; archegonia 210 $350 \mu \mathrm{m}$ long F. incurvus

5. Setae mostly lateral; male inflorescences budlike, often axillary; archegonia 160-220 $\mu \mathrm{m}$ long F. tosaensis

4. Capsules erect, symmetrical

6. Limbidia usually stoat on vaginant laminae, yellowish in older leaves; plants often $>5 \mathrm{~mm}$ long

7. Plants autoicous; setae terminal or on short axillary branches; antheridia usually in axillary bud-like perigonia $\cdots . F$. longisetus

7. Plants synoicous; setae terminal; antheridia mixed with archegonia ……….... F. geppii

6. Limbidia not as above; plants usually $<5 \mathrm{~mm}$ long

8. Setae usually lateral

F. bryoides var. lateralis

8. Setae always terminal

9. Antheridia usually axillary

10. Antheridia in bud-like perigonia …...

............. F. bryoides var. bryoides

10. Antheridia naked in the leaf axils .. .. F. gymnandrus

9. Antheridia not axillary

11. Plants synoicous or polyoicous ….....

…… F. bryoides var. ramosissimus

11. Plants rhizautoicous

12. Plants usually terricolous; perichaetial leaves not differentiated F. viridulus

12. Plants usually saxicolous; perichaetial leaves differentiated, much longer than cauline leaves

13. Perichaetial leaves 4-6(-7) times as long as wide, acute to obtuse at apex, costa usually ending below apex ……….... F. pusillus

13. Perichaetial leaves up to 9 times as long as wide, acuminate at apex, costa percurrent to excurrent $\cdots .$. F. gracilifolius

II. subgen. Fissidens sect. Polypodiopsis

10. Fissidens enervis Sim, Trans. Roy. Soc. South Africa 15: 187, 1926 (Figs. 1E, 2E).

Korean name: I-seul-bong-hwang-i-kki (이슬봉황이끼).

Plants pale green, $0.8-1.4 \mathrm{~mm}$ long and $0.5-0.7 \mathrm{~mm}$ wide with leaves. Stems unbranched; axillary hyaline nodules not differentiated. Leaves in 3-5 pairs, ecostae, upper leaves 
elliptical to ovate, $0.45-0.60 \times 0.14-0.20 \mathrm{~mm}$, acuminate to cuspidate at apex; base of dorsal laminae more or less rounded; margins entire; vaginant laminae ca. 1/2-3/5 the leaf length, equal; limbidia usually bistratose, thick-walled, extending to the apex; laminal cells large, unistratose, smooth, slightly protuberant, thin-walled; cells in the middle of apical and dorsal laminae hexagonal, $20-45 \times 12-28 \mu \mathrm{m}$; cells in the vaginant laminae narrower, $24-50 \times 10-17 \mu \mathrm{m}$; rhizoids often originating from laminal cells. Sporophytes not seen.

Specimens examined: KOREA. Gangwon-do: Jeongseongun, Gariwangsan Mountain, elev. 440 m, 21 Aug 2019, W. Kwon KBDS02442 (IN); Jeongseon-gun, Joyangsan Mountain, elev. 380 m, 15 Jul 2020, W. Kwon KBDSO3322 (IN).

Habitats: on moist soil in the trails.

Distribution: Southern Africa, India; new to Korea.

Fissidens enervis is a rare species of Fissidens in Asia. It was known to be distributed only in South Africa, however, the recent study reported the species in India for the first time in Asia (Bruggeman-Nannenga et al., 2016). This species is characterized by its ecostae leaves with cuspidate apex and remarkable rhizoids originating from laminal cells (BruggemanNannenga et al., 2016). It also has uni- to bistratose limbidia, contrary to $F$. hyalinus that only has unistratose limbidia (Bruggeman-Nannenga, 2017). Some expressions of $F$. hyalinus had small leaves with cuspidate apex, but neither bistratose limbidia nor rhizoids from laminae were present. Meanwhile, in Korea, $F$. enervis was currently found only in Jeongseon-gun, while F. hyalinus was in Jejudo Island, Wandogun, Geoje-si, Hapcheon-gun, Jeongseon-gun, and Yanggu-gun.

The Korean name was given as 'I-seul-bong-hwang-i-kki', based on its large, protuberant laminal cells.

\section{Key to the species of subgen. Fissidens sect. Polypodiopsis in Korea}

1. Protonemata persistent; plants bud-like $\cdot F$. protonemaecola

1. Protonemata not persistent; plants not bud-like

2. Limbidia usually bistratose, rhizoids often originating from laminal cells ………………………..... F. enervis

2. Limbidia unistratose, rhizoids not as above $\cdot F$. hyalinus

III. subgen. Fissidens sect. Aloma

11. Fissidens closteri subsp. kiusiuensis (Sakurai) Z. Iwats., J. Jap. Bot. 33: 249, 1958 (Figs. 1B, 2B).

Fissidens kiusiuensis Sakurai, Bot. Mag. (Tokyo) 47: 740, 1933.

Korean name: To-kki-bong-hwang-i-kki (토끼봉황이끼).
Plants vivid green to yellowish green, $0.6-1.2 \mathrm{~mm}$ long and 0.4-0.6 mm wide with leaves. Stems unbranched; axillary hyaline nodules not differentiated. Leaves in $2-3(-4)$ pairs, upper leaves elliptical-lanceolate to narrowly lanceolate, 0.5 $1.2 \times 0.13-0.22 \mathrm{~mm}$, acute at apex; base of dorsal laminae wedge-shaped; costa ending below the apex; margins entire to finely serrulate by projecting cells in upper laminae; vaginant laminae ca. 1/2-2/3 the leaf length, barely equal; elimbate; laminal cells unistratose, smooth; cells in the middle of apical and dorsal laminae irregularly, quadrate to narrowly hexagonal, $7-20(-27) \times 6-11 \mu \mathrm{m}$; cells in the vaginant laminae rectangular, enlarged, conspicuously elongated toward base, up to $40(-55)$ $\mu \mathrm{m}$ long; marginal cells of upper laminae smaller than the others, 7-15 × 5-8 $\mu \mathrm{m}$. Rhizautoicous. Archegonia terminal, 100-130 $\mu \mathrm{m}$ long. Antheridia in minute bud-like male shoots, ca. $100 \mu \mathrm{m}$ long. Setae 1.3-2.3 mm long. Capsules symmetrical, erect, urns $0.23-0.32 \times 0.16-0.21 \mathrm{~mm}$; opercula rostellate, $0.16-0.18 \mathrm{~mm}$ long; calyptrae cucullate, distinctly papillose by cells projecting at each upper end, ca. $0.3 \mathrm{~mm}$ long; peristome teeth $0.10-0.12 \mathrm{~mm}$ long, $20-28 \mu \mathrm{m}$ wide at base. Spores 8 $13 \mu \mathrm{m}$ in diameter.

Specimens examined: KOREA. Busan-si, Geumjeongsan Mountain, elev. 350 m, 19 Jul 2019, W. Kwon KBDS01865 (IN). Gangwon-do: Jeongseon-gun, Yujideungsan Mountain, elev. 400 m, 16 Jul 2020, W. Kwon KBDS03350 (IN); Yanggugun Dosolsan Mountain, elev. 660 m, 20 Aug 2020, W. Kwon KBDS03705 (IN). Jeollanam-do: Gwangyang-si, Baegunsan Mountain, elev. 1,090 m, 5 Sep 2020, W. Kwon KBDS03729 (IN). Gyeongsangnam-do: Hamyang-gun, Geumwonsan Mountain, elev. 1,160 m, 5 Sep 2020, W. Kwon KBDS03737 (IN).

Habitats: on rocks on trails, ridges, and side of streams.

Distribution: China, Japan; new to Korea.

Fissidens closteri Austin is a minute species characterized by its markedly short stems with well-differentiated leaves. The characteristic of stem is shared with other minute species, $F$. protonemaecola Sakurai and F. takayukii Tad. Suzuki, which have bud-like plants. However, F. closteri has the typical leaf structure of Fissidens, while F. protonemaecola and F. takayukii have somewhat reduced leaf structures. F. closteri subsp. kiusiuensis is an Asian subspecies recognized in China and Japan. It differs from the typical subspecies in having distinctly scabrous calyptrae with unipapillose surface cells projecting at each upper end.

The Korean name was given as 'To-kki-bong-hwang-i-kki', based on its leaf shape.

12. Fissidens flabellulus Thwait. \& Mitt., J. Linn. Soc., Bot. 13: 324, 1873 (Figs. 1F, 2F). 
Korean name: Bal-tob-bong-hwang-i-kki (발톱봉황이끼).

Plants pale green to yellowish green, 1.4-2.0 mm long and 0.8-1.2 mm wide with leaves. Stems unbranched; axillary hyaline nodules well-differentiated. Leaves in 3-6 pairs, upper leaves linear-lanceolate to lanceolate, $0.8-1.5 \times 0.12-0.27 \mathrm{~mm}$, acute at apex; base of dorsal laminae wedge-shaped; costae stoat, percurrent; margins finely crenulate to denticulate throughout by projecting cells; vaginant laminae ca. $2 / 5-1 / 2$ the leaf length, unequal, minor lamina \pm ending on the costa; elimbate; laminal cells unistratose, smooth, slightly protuberant; cells in the middle of apical and dorsal laminae usually hexagonal, $12-22(-30) \times 10-16 \mu \mathrm{m}$; cells in the vaginant laminae similar to those of apical and dorsal laminae, conspicuously elongated toward base, up to $45 \mu \mathrm{m}$ long. Sporophytes not seen.

Specimens examined: KOREA. Jeju-do: Seogwipo-si, Changgocheon Stream, elev. 190 m, 19 Jan 2020, W. Kwon KBDS02663 (IN).

Habitats: on muddy soil on the bank of the ephemeral stream.

Distribution: China, Fiji, India, Japan, Malaysia, Sri Lanka, Thailand, Vanuatu; new to Korea.

Fissidens flabellulus is a tropical Asian species, distributed in Southern and Eastern Asia (Tan et al., 2006). It is characterized by (1) minute plants with narrow leaves, (2) percurrent to shortly excurrent costae that often divide laminae unequally, and (3) crenulate to serrulate leaf margins with projecting cells ( $\mathrm{Li}$ et al., 2001). The species is separated from the related species, F. serratus C. Müll., which has smaller (8$11 \mu \mathrm{m})$ and unipapillose laminal cells, by its larger (10-19 $\mu \mathrm{m})$ and almost smooth laminal cells (Li et al., 2001).

The Korean name was given as 'Bal-tob-bong-hwang-i-kki', based on its leaf shape.

13. Fissidens takayukii Tad. Suzuki, Hattoria 6: 8, 2015 (Figs. 1M, 2M).

Korean name: Sae-ssak-bong-hwang-i-kki (새싹봉황이끼).

Plants yellowish green to brownish green, $0.5-0.7 \mathrm{~mm}$ long and $0.4-0.6 \mathrm{~mm}$ wide with leaves. Stems unbranched; axillary hyaline nodules not differentiated. Leaves in 1-2 pairs, upper leaves lanceolate, $0.5-0.6 \times 0.18-0.20 \mathrm{~mm}$, acute to caudate at apex, upper ends often slightly reflexed; apical and dorsal laminae not developed; costa percurrent to nearly percurrent, usually starting in the middle part of leaves; margins slightly denticulate throughout by projecting cells; elimbate; laminal cells unistratose, smooth; upper laminal cells irregularly quadrate, $12-15 \times 10-13 \mu \mathrm{m}$; middle laminal cells rectangular, conspicuously elongated toward base, up to $50 \mu \mathrm{m}$ long; marginal cells of leaves smaller than the others, $10-15 \times 5-8$ $\mu \mathrm{m}$. Rhizautoicous. Archegonia terminal, 130-160 $\mu \mathrm{m}$ long. Antheridia in minute bud-like male shoots near the base of female shoots, ca. $100 \mu \mathrm{m}$ long. Setae $1.5-2.0 \mathrm{~mm}$ long. Capsules symmetrical, erect, urns $0.35-0.48 \times 0.23-0.36 \mathrm{~mm}$; opercula conic-rostellate, $0.23-0.26 \mathrm{~mm}$ long; calyptrae cucullate, smooth to nearly smooth, ca. $0.4 \mathrm{~mm}$ long; peristome teeth $0.20-0.23 \mathrm{~mm}$ long, $26-35 \mu \mathrm{m}$ wide at base. Spores 9$12 \mu \mathrm{m}$ in diameter.

Specimens examined: KOREA. Jeju-do: Jeju-si, Cheonmicheon Stream, elev. 310 m, 21 Jan 2020, W. Kwon KBDS02885 (IN).

Habitats: on muddy soil on the bank of the ephemeral stream.

Distribution: Japan; new to Korea.

Fissidens takayukii is characterized by its peculiar scale-like leaf structure without differentiated apical and dorsal laminae. The costae of F. takayukii are percurrent, usually starting in the middle part of leaves (Suzuki, 2015). Its plants have minute bud-like appearances, similar to those of $F$. protonemaecola and F. closteri subsp. kiusiuensis. However, F. protonemaecola has persistent protonemata, and F. closteri subsp. kiusiuensis has leaves with well-differentiated laminae structure. The closely related species, Fissidens pseudoclosteri Z. Iwats. \& S. S. Kumar, has undifferentiated leaf structure significantly similar to F. takayukii (Tang et al., 2020). However, though the characteristic of calyptrae was not described in the original description (Iwatsuki and Kumar, 1992), F. pseudoclosteri has papillose calyptrae (Suzuki and Iwatsuki, 2012a) contrary to smooth calyptrae of F. takayukii (Suzuki, 2015). Korean materials of $F$. takayukii had smooth to nearly smooth calyptrae, not papillose. Meanwhile, the leaf structures of those two species were quite variable, comparative analyses through a multifarious approach should be required.

The Korean name was given as 'Sae-ssak-bong-hwang-ikki', based on its bud-like appearance.

\section{Key to the species of subgen. Fissidens sect. Aloma in Korea}

1. Plants not bud-like, elongated stems with distinctly pinnately arranged leaves ……………………. F. flabellulus

1. Plants bud-like, markedly short stems with \pm scale-like leaves

2. Leaves with well-differentiated apical and dorsal laminae F. closteri subsp. kiusiuensis 
2. Leaves without well-differentiated apical and dorsal laminae F. takayukii

\section{IV. subgen. Fissidens sect. Semilimbidium}

14. Fissidens ganguleei Nork., Mosses E. India 2: 527, 1971 (Figs. 1G, 2G).

Korean name: Nal-gae-bong-hwang-i-kki (날개봉황이끼).

Plants pale green to yellowish green, $2.0-4.0 \mathrm{~mm}$ long and $1.2-1.6 \mathrm{~mm}$ wide with leaves. Stems unbranched; axillary hyaline nodules not differentiated. Leaves in 5-12 pairs, upper leaves oblong-lanceolate, $0.6-1.3 \times 0.20-0.35 \mathrm{~mm}$, acute to mucronate at apex; base of dorsal laminae rounded to wedgeshaped; costae stoat, often bent angularly in cauline leaves, nearly percurrent to shortly excurrent; margins finely denticulate to crenulate throughout by projecting cells; vaginant laminae ca. 1/2-3/5 the leaf length, unequal, the upper part of minor lamina often ending on the costa; limbidia unistratose, 1-3 rows of elongate cells on the vaginant laminae of perichaetial leaves; laminal cells unistratose, smooth; cells in the middle of apical and dorsal laminae quadrate to hexagonal, $10-20 \times 6-14 \mu \mathrm{m}$; cells in the vaginant laminae similar to those of apical and dorsal laminae; marginal cells \pm differentiated, somewhat smaller than the others, 8-12 $\times 6-12$ $\mu \mathrm{m}$ in upper laminae; a conspicuous central oil globule found in each laminal cell. Dioicous? Archegonia terminal, 360-400 $\mu \mathrm{m}$ long. Antheridia terminal, 190-220 $\mu \mathrm{m}$ long. Sporophytes not seen.

Specimens examined: KOREA. Jeju-do: Seogwipo-si, Akgeunnae Stream, elev. 310 m, 20 Jan 2020, W. Kwon KBDS02759 (IN). Jeollanam-do: Gwangyang-si, Baegunsan Mountain, elev. 1,030 m, 5 Sep 2020, W. Kwon KBDS03720 (IN).

Habitats: on moist soil and rocks, usually in shaded backslopes or trails of mountains (elev. 1,000-1,400 m); rarely on hard earth banks of the ephemeral stream.

Distribution: Bangladesh, China, India, Indonesia, Japan, Laos, Nepal, Vietnam; new to Korea.

Fissidens ganguleei, the Asian species, was originally described in India and recorded in several Asian countries (Zhang et al., 2016). This species is characterized by its leaves with (1) often bent costa, (2) the upper part of minor vaginant lamina ending on the costa, (3) tapered dorsal lamina that slightly decurrent, and (4) more or less thin-walled laminal cells (Noguchi, 1987; Li et al., 2001). These characteristics are also shared in the European species, F. celticus Paton, which is recognized as a West-European endemic moss (Vanderpoorten and Sotiaux, 2002; Guerra et al., 2012). This species has well- marked leaves characterized by (1) distinctly bent costa, (2) unequal vaginant laminae the upper part of which is ending on the costa, and (3) laminal cells that $8-12 \mu \mathrm{m}$ wide in the marginal row and 12-20 $\mu \mathrm{m}$ wide in the rest (Paton, 1965). Japanese and Chinese authors described $F$. ganguleei as having broader (0.2-0.3 mm wide) leaves with smaller ( $7-15 \mu \mathrm{m}$ long) laminal cells (Noguchi, 1987; Li et al., 2001), while F. celticus having narrower $(0.16-0.23 \mathrm{~mm}$ wide) leaves with somewhat larger $(8-16 \times 12-20 \mu \mathrm{m})$ laminal cells (Paton, 1965). Meanwhile, Korean materials had $0.20-0.35 \mathrm{~mm}$ wide leaves, with 10-20 × 6-14 $\mu \mathrm{m}$ laminal cells.

Though Pursell and Bruggeman-Nannenga (2004) did not divide the subgen. Aloma into sections, the two species were generally regarded as belonging to the sect. Aloma (Vanderpoorten and Sotiaux, 2002; Suzuki and Iwatsuki, 2012b). However, the recent study of the infrageneric classification of Fissidens based on molecular phylogeny treated $F$. ganguleei as a member of the sect. Semilimbidium (Suzuki et al., 2018). As with the members of the sect. Semilimbidium, F. celticus also has the weakly differentiated limbidia with elongate cells on the vaginant laminae of perichaetial leaves, as referred to the original description of $F$. celticus (Paton, 1965). In consequence, I expected that $F$. ganguleei and F. celticus are close relative in the aspect of phylogeny because both species share the particular morphological features. Meticulous studies are essential for clarifying the species delimitation.

The Korean name was given as 'Nal-gae-bong-hwang-i-kki', based on its leaf shape.

15. Fissidens wichurae Broth. \& Fleisch., Hedwigia 38: 127, 1899 (Figs. 1O, 2O).

Korean name: Kal-ip-bong-hwang-i-kki (칼잎봉황이끼).

Plants yellowish green to dark green, 2.0-3.0 mm long, 1.5$1.8 \mathrm{~mm}$ wide with leaves. Stems unbranched; axillary hyaline nodules weakly differentiated. Leaves in 4-7 pairs, upper leaves narrowly lanceolate, $1.4-1.8 \times 0.16-0.23 \mathrm{~mm}$, acuminate at apex; base of dorsal laminae wedge-shaped; costa shortly excurrent; margins finely crenulate throughout by projecting cells; vaginant laminae ca. $1 / 2-3 / 5$ the leaf length, equal; limbidia unistratose, (0-)2-4 rows of elongate cells on the lower parts of vaginant laminae; laminal cells unistratose, pluripapillose, obscure; cells in the middle of apical and dorsal laminae quadrate to hexagonal, $5-10 \times 5-7 \mu \mathrm{m}$; cells in the vaginant laminae similar to those of apical and dorsal laminae; basal juxtacostal cells of vaginant laminae smooth, rectangular, conspicuously enlarged, up to $30 \mu \mathrm{m}$ long. Sporophytes not seen. 
Specimens examined: KOREA. Gyeongsangnam-do: Geoje-si, Bukbyeongsan Mountain, elev. 80 m, 08 Feb. 2019, W. Kwon KBDS01330 (IN).

Habitats: on soil of slopes on the mountain.

Distribution: China, Indonesia, Japan, Malaysia, New Guinea, Philippines, Thailand; new to Korea.

Fissidens wichurae is characterized by its weakly differentiated axillary hyaline nodules, which are not differentiated in F. linearis var. obscurirete (Broth. \& Par.) Stone (Li et al., 2001). In addition, $F$. wichurae has narrower leaves with distinct limbidial cells in most leaves, while those of $F$. linearis var. obscurirete are restricted to perichaetial leaves (Suzuki and Iwatsuki, 2012a).

The Korean name was given as 'Kal-ip-bong-hwang-i-kki', based on its leaf shape.

\section{Key to the species of subgen. Fissidens sect. Semilimbidium in Korea}

1. Laminal cells smooth F. ganguleei

1. Laminal cells mamillose or papillose

2. Laminal cells highly mamillose or with $1(-2)$ indistinct papillae F. crenulatus

2. Laminal cells with 4-6 papillae

3. Costae ending below the apex

4. Vaginant laminae unequal; peristome teeth undivided or incompletely divided $\cdots F$. gardneri

4. Vaginant laminae more or less equal; peristome teeth clearly divided …………...... F. pallidinervis

3. Costae percurrent to excurrent

5. Upper leaves narrowly lanceolate, axillary hyaline nodules indistinct $\cdots \cdots \cdot$. F. linearis var. obscurirete

5. Upper leaves linear-lanceolate, axillary hyaline nodules weakly differentiated …….... F. wichurae

ORCID: Woochan KWON https://orcid.org/0000-0001-86658097

\section{Acknowledgments}

I appreciate anonymous reviewers for their helpful comments on my manuscript. I also give thanks to Myungjun Jang, Jaehyun Shim, and Hansol Chang for proofreading the manuscript to improve English. This work was also supported by 'The Consortium of Korea Biodiversity and Sustainable Use' at the Ministry of Environment, Korea.

\section{Conflict of Interest}

The author declares that there are no conflicts of interest.

\section{Literature Cited}

Atherton, I., S. D. S. Bosanquet and M. Lawley. 2010. Mosses and Liverworts of Britain and Ireland: A Field Guide. British Bryological Society, Plymouth, 848 pp.

Bordin, J., R. A. Pursell and O. Yano. 2011. Fissidens pseudoplurisetus sp. nov. (Fissidentaceae, subgenus Aloma), from the Atlantic Forest, Brazil. The Bryologist 114: 785-789.

Brotherus, V. F. 1921. Musci novi japonici. Öfversigt af Finska Vetenskaps-Societetens Förhandlingar 62: 1-55.

Bruggeman-Nannenga, M. A. 2013. Subgenus Fissidens in tropical Eastern Africa with emphasis on the Tanzanian collections by Tamás Pócs. Polish Botanical Journal 58: 369-417.

Bruggeman-Nannenga, M. A. 2017. Fissidens Subgenus Aloma (Bryophyta) in Tropical Africa I. The large-celled costate and ecostate species. Polish Botanical Journal 62: 139-168.

Bruggeman-Nannenga, M. A., K. M. Manjula and C. N. Manju. 2016. Fissidens enervis (Fissidentaceae; Bryophyta) new to Asia. Lindbergia 39: 29-32.

Bruggeman-Nannenga, M. A. and R. A. Pursell. 1995. Notes on Fissidens V. Lindbergia 20: 49-55.

Bruggeman-Nannenga, M. A., R. A. Pursell and Z. Iwatsuki. 1994. A re-evaluation of Fissidens subgenus Serridium section Amblyothallia. The Journal of the Hattori Botanical Laboratory 77: 255-271.

Cardot, J. 1904. Première contribution à la flore bryologique de la Corée. Beihefte zum botanischen Centralblatt 17: 1-44.

Corley, M. F. V. 1980. The Fissidens viridulus complex in the British Isles and Europe. Journal of Bryology 11: 191-208.

Crosby, M. R., R. E. Magill, B. Allen and S. He. 2000. A Checklist of the Mosses. Missouri Botanical Garden Press, St. Louis, MO, 320 pp.

Erzberger, P. 2016. The genus Fissidens (Fissidentaceae, Bryophyta) in Hungary. Studia Botanica Hungarica 47: 41-139.

Guerra, J., P. Heras and M. Infante. 2012. Fissidens bryoides var. gymnandrus and F. celticus (Bryophyta, Fissidentaceae) in the Iberian Peninsula. Cryptogamie, Bryologie 33: 149-154.

Hassel, K., R. Segreto and T. Ekrem. 2013. Restricted variation in plant barcoding markers limits identification in closely related bryophyte species. Molecular Ecology Resources 13: 1047-1057.

Hill, M. O., N. Bell, M. A. Bruggeman-Nannenga, M. Brugués, M. J. Cano, J. Enroth, K. I. Flatberg, J. P. Frahm, M. T. Gallego, R. Garilleti, J. Guerra, L. Hedenäs, D. T. Holyoak, J. Hyvönen, M. S. Ignatov, F. Lara, V. Mazimpaka, J. Muñoz and 
L. Söderström. 2006. An annotated checklist of the mosses of Europe and Macronesia. Journal of Bryology 28: 198-267.

Huttunen, S., R. Juutinen and K. E. M. Vuorinen. 2018. Taxonomy, ecology and conservation status of the mosses Fissidens bryoides, F. gymnandrus and F. viridulus in Finland. Annales Botanici Fennici 55: 339-358.

Iwatsuki, Z. and S. S. Kumar. 1992. Some interesting mosses from India. Hikobia 11: 133-137.

Iwatsuki, Z. and T. Suzuki. 1982. A taxonomic revision of the Japanese species of Fissidens (Musci). Journal of the Hattori Botanical Laboratory 51: 329-508.

Kim, W., M. Higuchi and T. Yamaguchi. 2020a. An updated list of mosses of Korea. Journal of Species Research 9: 377-412.

Kim, W., M. Higuchi, T. Yamaguchi, T. Sato and Y. Inoue. 2020b. New and noteworthy records of the moss flora of Korea. Korean Journal of Plant Taxonomy 50: 419-426.

Kwon, W., J. Min, H. Xi and J. Park. 2019a. The complete chloroplast genome of Fissidens nobilis Griff. (Fissidentaceae, Bryophyta). Mitochondrial DNA Part B 4: 2225-2226.

Kwon, W., Y. Kim and J. Park. 2019b. A new record of Fissidens protonemaecola Sakurai (Fissidentaceae, Bryophyta) in Korea. Korean Journal of Plant Taxonomy 49: 265-268.

Lee, J.-Y. and B.-H. Choi. 2012. A history of bryological studies on the Korean Peninsula. Korean Journal of Plant Taxonomy 42: 109-115.

Li, X. J., M. R. Crosby, S. He and Z. Iwatsuki. 2001. Moss Flora of China, vol. 2. Fissidentaceae-Ptychomitriaceae. Missouri Botanical Garden Press, Beijing, 283 pp.

Noguchi, A. 1987. Illustrated Moss Flora of Japan. Vol. 1. Hattori Botanical Laboratory, Nichinan. Pp. 57-86.

Park, K. W. and K. Choi. 2007. New List of Bryophytes in Korea. Korea National Arboretum, Pocheon. Pp. 1-75. (in Korean)

Paton, J. A. 1965. A new British moss, Fissidens celticus sp. nov. Transactions of the British Bryological Society 4: 780-784.

Pursell, R. A. 1994. Taxonomic notes on neotropical Fissidens. Bryologist 97: 253-271.

Pursell, R. A. 2007. 21. Fissidentaceae Schimper. Flora of North America 27: 331-357.

Pursell, R. A. and B. Allen. 1996. A comparison of Fissidens appalachensis and F. bryoides var. pusillus. Bryologist 99: 75-80.

Pursell, R. A. and B. Allen. 2017. Fissidens of Delaware and adjacent areas. Evansia 34: 134-151.

Pursell, R. A. and M. A. Bruggeman-Nannenga. 2004. A revision of the infrageneric taxa of Fissidens. The Bryologist 107: 1-20.

Ros, R. M., J. A. Jiménez, M. J. Cano, R. A. Pursell, M. A. BruggemanNannenga and G M. Dirkse. 2001. Fissidens sublimbatus, new to Morocco and the Canary Islands. The Bryologist 104: 468-470.

Sakurai, K. 1942. Beobachtungen über japanische Moosflora.
XXV. Botanical Magazine, Tokyo 56: 217-224.

Shevock, J. R., R. A. Pursell, C. A. Garcia, M. A. BruggemanNannenga and C. Sérgio. 2013. The genus Fissidens in the Republic of São Tomé and Príncipe, Gulf of Guinea, West Africa. Journal of Bryology, 35: 197-205.

Smith, A. J. E. 2004. The Moss Flora of Britain and Ireland. Cambridge University Press, Cambridge. Pp. 241-247.

Spence, J. R. 2005. New genera and combinations in Bryaceae (Bryales, Musci) for North America. Phytologia 87: 15-28.

Spence, J. R. 2007. Nomenclatural changes in the Bryaceae (Bryopsida) for north America II. Phytologia 89: 110-114.

Suzuki, T. 2015. Notes on Fissidens (Fissidentaceae, Bryopsida) in Japan. Hattoria 6: 1-25.

Suzuki, T., Y. Inoue and H. Tsubota. 2018. Molecular phylogeny of the genus Fissidens (Fissidentaceae, Bryophyta) and a refinement of the infrageneric classification. Molecular Phylogenetics and Evolution 127: 190-202.

Suzuki, T. and Z. Iwatsuki. 2008. Fissidens longisetus Griff. newly found in Japan. Bryological Research 9: 255-258.

Suzuki, T. and Z. Iwatsuki. 2012a. Fissidens (Fissidentaceae, Bryopsida) species newly found in Japan. Hattoria 3: 1-48.

Suzuki, T. and Z. Iwatsuki. 2012b. Keys to the subgenera, sections, and species of Fissidens in Japan. Hattoria 3: 49-56.

Syazwana, N., N. Norhazrina, H. Maideen, K. T. Yong and M. Suleiman. 2018. Towards a revision of the moss genus Fissidens (Fissidentaceae) in Peninsular Malaysia. Malayan Nature Journal 70: 297-307.

Tan, B. C., K. Vongkuna, S. Manachit and K. Santanachote. 2006. New records of Thailand mosses collected from Chiang Mai Province. Tropical Bryology 27: 95-100.

Tang, Q.-M., B.-C. Ho and Y.-M. Wei. 2020. New national records and range extensions of the moss genus Fissidens (Fissidentaceae) from Guangxi, China. Hattoria 11: 41-60.

Thériot, I. 1908. Diagnoses d'espèces et de variétés nouvelles de mousses (5e article). Bulletin de l'Académie Internationale de Géographie Botanique 18: 250-254.

Vanderpoorten, A. and A. Sotiaux. 2002. Distribution and ecology of Fissidens celticus J.A. Paton (Fissidentaceae, Bryopsida) in continental Europe. Nova Hedwigia 74: 461-464.

Yoon, Y. J. and B.-Y. Sun. 2010. Four unrecorded moss species from the Korean flora. Korean Journal of Plant Taxonomy 40: 186-191.

Yoon, Y.-J., B. C. Tan, C.-H. Kim and B.-Y. Sun. 2015a. Ten new records of South Korean mosses. Arctoa 24: 37-42.

Yoon, Y.-J., B. C. Tan and B.-Y. Sun. 2015b. Seven new records of overlooked South Korean moss species. Hattoria 6: 57-61.

Zhang, B.-Y., L. Shu, C.-X. Zhao, Y.-M. Wei, J. Wang, T. Van Do, T. N. Lu, Y.-F. Wang and R.-L. Zhu. 2016. New moss records for Vietnam. Cryptogamie, Bryologie 37: 259-281. 
Appendix 1. The list of Fissidens in Korea (*new to Korea).

\begin{tabular}{|c|c|}
\hline No. & Taxa \\
\hline \multicolumn{2}{|c|}{ Subgen. Fissidens } \\
\hline \multicolumn{2}{|c|}{ Sect. Fissidens } \\
\hline 1 & Fissidens bryoides Hedw. \\
\hline 2 & Fissidens bryoides var. esquirolii (Thér.) Z. Iwats. \& T. Suzuki* \\
\hline 3 & Fissidens bryoides var. lateralis (Broth.) Z. Iwats. \& Tad. Suzuki \\
\hline 4 & Fissidens bryoides var. ramosissimus Thér. \\
\hline 5 & Fissidens crispus Mont.* \\
\hline 6 & Fissidens curvatus Hornsch.* \\
\hline 7 & Fissidens geppii M. Fleisch. \\
\hline 8 & Fissidens gymnandrus Buse* \\
\hline 9 & Fissidens incurvus Starke ex Röhl* \\
\hline 10 & Fissidens longisetus Griff.* \\
\hline 11 & Fissidens pusillus (Wilson) Milde* \\
\hline 12 & Fissidens tosaensis Broth. \\
\hline 13 & Fissidens viridulus (Sw.) Wahlenb.* \\
\hline \multicolumn{2}{|c|}{ Sect. Polypodiopsis } \\
\hline 14 & Fissidens enervis Sim* \\
\hline 15 & Fissidens hyalinus Wilson \& Hook. \\
\hline 16 & Fissidens protonemaecola Sakurai \\
\hline \multicolumn{2}{|c|}{ Sect. Aloma } \\
\hline 17 & Fissidens closteri subsp. kiusiuensis (Sakurai) Z. Iwats.* \\
\hline 18 & Fissidens flabellulus Thwait. \& Mitt.* \\
\hline 19 & Fissidens takayukii Tad. Suzuki* \\
\hline \multicolumn{2}{|c|}{ Sect. Semilimbidium } \\
\hline 20 & Fissidens crenulatus Mitt. \\
\hline 21 & Fissidens ganguleei Nork.* \\
\hline 22 & Fissidens gardneri Mitt. \\
\hline 23 & Fissidens linearis var. obscurirete (Broth. \& Paris) I. G. Stone \\
\hline 24 & Fissidens pallidinervis Mitt. \\
\hline 25 & Fissidens wichurae Broth. \& Fleisch.* \\
\hline \multicolumn{2}{|c|}{ Subgen. Neoamblyothallia } \\
\hline \multicolumn{2}{|c|}{ Sect. Crispidium } \\
\hline 26 & Fissidens crispulus Brid. \\
\hline 27 & Fissidens crispulus var. robinsonii (Broth.) Z. Iwats. \& Z. H. Li \\
\hline \multicolumn{2}{|c|}{ Subgen. Pachyfissidens } \\
\hline 28 & Fissidens adianthoides Hedw. \\
\hline 29 & Fissidens anomalus Mont. \\
\hline 30 & Fissidens dubius P. Beauv. \\
\hline 31 & Fissidens geminiflorus Dozy \& Molk. \\
\hline 32 & Fissidens grandifrons Brid. \\
\hline 33 & Fissidens gymnogynus Besch. \\
\hline 34 & Fissidens involutus var. jejuensis Y. J. Yoon, B. C. Tan \& B. Y. Sun \\
\hline 35 & Fissidens nobilis Griff. \\
\hline 36 & Fissidens osmundoides Hedw. \\
\hline 37 & Fissidens taxifolius Hedw. \\
\hline 38 & Fissidens teysmannianus Dozy \& Molk. \\
\hline
\end{tabular}

